HORTSCIENCE 26(10):1305-1308. 1991.

\title{
Root Carbohydrate, Organic Acids, and Phenolic Chemistry in Relation to Sweetpotato Weevil Resistance
}

\author{
Ki-Cheol Son' \\ Department of Horticulture, University of Georgia, Athens, GA 30602
}

\author{
Ray F. Severson and Maurice E. Snook \\ Phytochemical Research Unit, Agricultural Research Service, U.S. \\ Department of Agriculture, Athens, GA 30613
}

\author{
Stanley J. Kays \\ Department of Horticulture, University of Georgia, Athens, GA 30602
}

Additional index words. fructose, $\alpha$-glucose, $\beta$-glucose, sucrose , inositol, chlorogenic acid, malic acid, citric acid, dicaffeoylquinic acids, rutin. Ipomoea batatas. Cylas

formicarius elegantulus

\begin{abstract}
Methanol extracts of external (outer $3 \mathrm{~mm}$ ) and interior root tissue of four sweetpotato [Ipomoea batatas (L.) Lam.] cultivars ('Centennial', 'Jewel', 'Regal', and 'Resisto') having different levels of susceptibility to the sweetpotato weevil [Cylas formicarius elegantulus Summer] were analyzed for simple carbohydrates (fructose, glucose, sucrose, inositol) and organic acids (malic, citric, quinic) by gas chromatography and for phenolics (caffeic acid, caffeoylquinic acids, rutin) by high-performance liquid chromatography. There were significant differences among cultivars in the concentrations of total sugars and phenolics in the external tissue $(P<0.05)$. In addition, the distribution of carbohydrates, organic acids, and chlorogenic acid [3-O-caffeoylquinic acid] differed between external and interior tissues. Sucrose was the major watersoluble carbohydrate in all cultivars. With the exception of malic acid, the concentration of carbohydrates, organic acids, and phenolics did not correlate with cultivar susceptibility to the sweetpotato weevil.
\end{abstract}

The surface of sweetpotato storage roots contains allelochemicals that affect the behavior of the sweetpotato weevil. A root volatile fraction, whose major constituents were sesquiterpenes, attracted adult females (Nottingham et al., 1989a), and a nonvolatile pentacyclic triterpene, boehmeryl acetate (Son et al., 1990), was found to stimulate oviposition (Wilson et al., 1989). In addition, there is a positive correlation between feeding rate of the female on the root and oviposition frequency (Nottingham et al., 1989b).

Weevil larvae feed and develop within the storage root in which the egg is laid and do

Received for publication 16 Apr. 1990. The cost of publishing this paper was defrayed in part by the payment of page charges. Under postal regulations, this paper therefore must be hereby marked advertisement solely to indicate this fact. not migrate to other roots (Sutherland, 1986). Thus, their developmental potential depends on the ovipositional site selected by the adult female. As a consequence, it is probable that root chemistry is as intimately involved in modulating adult and larval feeding as it is with oviposition; however, this behavior has not been demonstrated. Likewise, the nutritional requirements of the larvae and adult weevils are not known. As a consequence, information is needed on the type and concentration of constituents that initiate feeding in adults and larvae and regarding the nutrients required for larval development. This would allow development of an artificial diet for the weevil that then could be used to evaluate the importance of individual root constituents during the larva's development.

We determined the concentrations of simple carbohydrates, organic acids, and phenolics in the roots of four cultivars that have 
Table 1. Concentration of carbohydrates and organic acids in the external tissue (outer $3 \mathrm{~mm}$ ) of storage roots from four sweetpotato cultivars as determined by gas chromatography.

\begin{tabular}{|c|c|c|c|c|c|c|c|c|}
\hline & $\alpha$-Glucose & $\beta$-Glucose & Sucrose & Inositol & $\begin{array}{c}\text { Total }^{2} \\
\text { sugars }\end{array}$ & $\begin{array}{l}\text { Malic } \\
\text { acid }\end{array}$ & $\begin{array}{l}\text { Fructose and } \\
\text { citric acid }\end{array}$ & $\begin{array}{l}\text { Quinic } \\
\text { acid }\end{array}$ \\
\hline Cultivar & \multicolumn{8}{|c|}{$\mathrm{mg} \cdot \mathrm{g}^{-1}$ fresh wt $\pm \mathrm{SE}$} \\
\hline Centennial $(\mathrm{S})^{\mathrm{y}}$ & $1.05 \pm 0.06^{x}$ & $1.87 \pm 0.11$ & $37.60 \pm 1.5$ & $0.36 \pm 0.01$ & $44.11 \pm 2.9$ & $0.25 \pm 0.02$ & $3.59 \pm 0.2$ & $1.05 \pm 0.01$ \\
\hline Jewel (MR) & $2.26 \pm 0.07$ & $3.98 \pm 0.11$ & $42.62 \pm 1.3$ & $0.18 \pm 0.01$ & $59.27 \pm 3.0$ & $0.63 \pm 0.06$ & $10.41 \pm 0.4$ & $1.51 \pm 0.06$ \\
\hline Regal (MR) & $1.15 \pm 0.04$ & $1.88 \pm 0.04$ & $19.47 \pm 1.1$ & $0.61 \pm 0.02$ & $27.16 \pm 2.4$ & $1.49 \pm 0.06$ & $4.66 \pm 0.1$ & $1.35 \pm 0.14$ \\
\hline Resist & $0.51 \pm 0.02$ & $0.89 \pm 0.04$ & $46.60 \pm 1.6$ & $0.67 \pm 0.03$ & $50.52 \pm 3.4$ & $1.33 \pm 0.09$ & $2.52 \pm 0.1$ & $0.69 \pm 0.03$ \\
\hline $\mathrm{LSD}_{0.05}(\mathrm{MR})$ & 0.14 & 0.22 & 3.70 & 0.05 & 3.96 & 0.17 & 0.58 & 0.20 \\
\hline
\end{tabular}

zTotal sugars $=$ composite of fructose, $\alpha$ - and $\beta$-glucose, inositol, and sucrose.

y $\mathrm{S}=$ weevil-susceptible line, $\mathrm{MR}=$ lines with moderate levels of resistance to the sweetpotato weevil.

${ }^{x}$ Mean of replicates $\pm \mathrm{SE}$.

Table 2. Concentration of phenolics of external tissue (outer $3 \mathrm{~mm}$ ) of sweetpotato storage roots from four cultivars.

\begin{tabular}{|c|c|c|c|c|c|c|c|c|c|c|c|}
\hline \multirow[b]{3}{*}{ Cultivar } & \multirow{2}{*}{\multicolumn{2}{|c|}{$\begin{array}{c}\text { Chlorogenic } \\
\text { acid }\end{array}$}} & \multirow{2}{*}{\multicolumn{2}{|c|}{$\begin{array}{c}\text { Caffeic } \\
\text { acid }\end{array}$}} & \multicolumn{4}{|c|}{ Dicaffeoylquinic acid } & \multirow{2}{*}{\multicolumn{2}{|c|}{ Rutin }} & \multirow{2}{*}{$\begin{array}{c}\text { Total }^{\mathbf{x}} \\
\text { phenolics }\end{array}$} \\
\hline & & & & & & 1 & & 2 & & & \\
\hline & \multicolumn{11}{|c|}{$\mathrm{mg} \cdot \mathrm{g}^{-1}$ fresh $\mathrm{wt}^{\mathrm{z}}$ (relative distribution) } \\
\hline Centennial & $1.37 \mathrm{~b}^{y}$ & $(14.9 b)^{x}$ & $0.84 \mathrm{~b}$ & $(9.2 \mathrm{~b})$ & $3.44 \mathrm{a}$ & $(37.5 \mathrm{a})$ & $2.94 \mathrm{a}$ & $(32.1 \mathrm{~b})$ & $0.58 \mathrm{a}$ & $(6.3 \mathrm{a})$ & $9.17 \mathrm{a}$ \\
\hline Jewel & $0.53 \mathrm{~d}$ & $(14.0 \mathrm{~b})$ & $1.38 \mathrm{a}$ & $(36.4 \mathrm{a})$ & $0.89 \mathrm{c}$ & $(23.5 \mathrm{~b})$ & $0.79 \mathrm{c}$ & $(20.8 \mathrm{c})$ & $0.20 \mathrm{~b}$ & $(5.3 \mathrm{ab})$ & $3.79 \mathrm{c}$ \\
\hline Regal & $1.72 \mathrm{a}$ & $(44.0 \mathrm{a})$ & $0.34 \mathrm{~d}$ & $(8.7 \mathrm{~b})$ & $0.98 \mathrm{c}$ & $(25.1 \mathrm{~b})$ & $0.74 \mathrm{c}$ & $(18.9 \mathrm{c}\rangle$ & $0.13 \mathrm{c}$ & $(3.3 c)$ & $3.91 \mathrm{c}$ \\
\hline Resisto & $0.96 \mathrm{c}$ & $(14.5 \mathrm{~b})$ & $0.54 \mathrm{c}$ & $(8.2 \mathrm{~b})$ & $2.55 \mathrm{~b}$ & $(38.5$ a) & $2.28 \mathrm{~b}$ & (34.4 a) & $0.29 \mathrm{bc}$ & $(4.4 \mathrm{bc})$ & $6.62 \mathrm{~b}$ \\
\hline $\operatorname{LSD}_{0.05}$ & 0.22 & 4.4 & 0.33 & 2.4 & 0.68 & 2.7 & 0.61 & 2.5 & 0.12 & 1.4 & 0.10 \\
\hline
\end{tabular}

${ }^{2}$ Calculated relative to the levels of chlorogenic acid as determined by gas chromatography.

${ }^{y}$ Separation of means within columns by $\mathrm{LSD}_{005}$.

${ }^{\mathrm{x}}$ Concentration of total phenolics on a fresh-weight basis, relative distribution in parentheses.

been demonstrated to possess varying levels of susceptibility to the sweetpotato weevil in field (Jones et al., 1983, 1985; Mullen et al., 1985) and laboratory tests (Nottingham et al., 1987) to ascertain if these components may be important in differences in susceptibility. Constituents were quantified using capillary gas chromatography (GC) and highperformance liquid chromatography (HPLC).

Four sweetpotato cultivars ('Centennial', 'Jewel', 'Regal', and 'Resisto') were grown according to recommended agronomic practices at the Univ. of Georgia's horticulture farm. Slips were planted in early June, and storage roots were harvested during the first week of October. After harvest, the roots were cured and stored under standard conditions (13C, $85 \%$ relative humidity). For analysis, roots having surface areas of 120 to $150 \mathrm{~cm}^{2}$ and similar shape were selected, washed with tap water, and the surface airdried.

Distilled-in-glass-grade methanol $(\mathrm{MeOH})$ (Burdick and Jackson, Muskegon, Mich.) and silylation-grade dimethylformide (DMF) and $\mathrm{N}$, O-bis (trimethyl silyl)-trifluoroacetamide (BSTFA) (Pierce Chemical Co., Rockford, Ill.) were used. Standard compounds-Lmalic acid (Eastman Organic, Rochester, N.Y.), D(-)-fructose and D-sucrose (Fluka, Ronkonkoma, N.Y.), citric acid (Chem Service, West Chester, Pa.), quinic acid (Fluka), chlorogenic acid (3-O-caffeovlquinic acid, 3-O-CQA) (Fluka), isochlorogenic acid (a mixture of dicaffeoylquinic acids) (Fluka), phenyl ß-D-glucopyranoside (Aldrich, Milwaukee), B-D-glucose (Analabs), $\boldsymbol{\alpha} \cdot \mathrm{D}$-glucose (Supelco, Bellefonte, Pa.), and inositol (Aldrich) -were used as received.

Individual extracts were made from tissue taken from five storage roots using a no. 11 cork borer. Each core was dissected with a razor into two tissue types, external (the outer
$3 \mathrm{~mm}$ of surface tissue) and interior (secondary root tissue found internal to the cambium). For each sample, 530 to $570 \mathrm{mg}$ of tissue was weighed into a $20-\mathrm{ml}$ scintillation vial and $15 \mathrm{ml}$ of $\mathrm{MeOH}$ was added. The sample was homogenized using a Virtis " 45 " tissue homogenizer (Virtis, Gardner, N. Y.) for 3 rein, the vial sealed using a teflon-lined cap, and then ultrasonicated for $30 \mathrm{~min}$. Following filtering, the stock solution was stored at $-18 \mathrm{C}$ until analysis.

In experiments where only external tissue was analyzed, a core sample was taken from each of five storage roots selected from different parent plants. Five replications of each treatment were analyzed. In experiments designed to prevent artifact formation of free caffeic acid, fresh and stored roots were washed briefly in cold water and the external tissue removed with a potato peeler. The peels were cut into $\approx 2 \mathrm{~mm}$ lengths, immediately placed in $\mathrm{MeOH}$, and ground to a fine mesh with a Brinkman tissue homogenizer (Polytron; Brinkman Instruments, Westbury, N.Y.). Total time from peeling to grinding did not exceed $5 \mathrm{~min}$. The MeOH slurry was filtered and the extract immediately analyzed by HPLC and GC.

'Centennial' roots were used to compare the chemistry between external and interior tissue. A 3-ml homogenized sample of external tissue was partitioned consecutively with 1 and $2 \mathrm{ml}$ of hexane to remove nonpolar peridermal lipids and waxes. The methanol fraction was then analyzed for carbohydrates, organic acids, and phenolics. The absence of these components in the hexane fraction was confirmed by GC analysis. The experiment was replicated three times.

Samples were gas-chromatographed after warming to room temperature, A portion of the stock solution (equivalent to 15 to $20 \mathrm{mg}$ of root fresh weight) and $15 \mu \mathrm{l}$ of internal standard solution (ISTD; phenyl-ß-D-glucopyranoside, $8.89 \mu \mathrm{g} \cdot \mu^{-1}$ in $\left.\mathrm{MeOH}\right)$ were transferred to a microautosampler vial and the solvent removed under $\mathrm{N}_{2}$ at $40 \mathrm{C}$. A 75 $\mu \mathrm{l}$ portion of 1 BSTFA :1 DMF was added to the residue, the vial sealed with a crimp cap, sonicated for 30 rein, and then heated for $50 \mathrm{~min}$ at $76 \mathrm{C}$.

Sugars and organic acids were analyzed on a Hewlett-Packard (Palo Alto, Calif.) 5890A gas chromatography (equipped with a 7673A automatic sampler, split-splitless injection port, and flame ionization detector) using a $0.5 \mathrm{~mm}$ i.d. $\times 12 \mathrm{~m} \mathrm{SE-54}$ fused silica capillary column. The temperature program was $100 \mathrm{C}$ for 1 rein, then increased at $7 \mathrm{C} / \mathrm{min}$ to $320 \mathrm{C}$ with a $25-\mathrm{min}$ postrun holding time. The injection port and detector were at 250 and $325 \mathrm{C}$, respectively. One microliter of each sample was injected in the splitless mode using a l-rein purge activation time.

Constituent concentrations, using chromatographic response of authentic compounds, were calculated using ISTD methodology with a HP 3393A computing integrator. Data were calculated on a milligram per gram of fresh weight basis. Each component in the root samples was identified by comparisons of GC/MS spectra and GC retention data with authentic standards. Statistically significant differences $(P<$ 0.05 ) between cultivars in the concentration of individual components were determined by analysis of variance, and means were separated according to Fisher's least significant difference (LSD) test (SAS, 1985).

Polyphenols were analyzed by HPLC via the method of Snook et al. (1986) using two Altex (Berkeley, Calif.) model 110 pumps, an Altex 420 solvent programmer, and an Altex model 500 autosampler. An aliquot of the stock solution was filtered through a 0.45 $\mu$ Nylon 66 membrane (MSI, Fisher Scien- 
Table 3. Ratio of carbohydrates, organic acids, and chlorogenic acid between external and interior tissues of 'Centennial' storage roots.

\begin{tabular}{cccccccc}
\hline $\begin{array}{c}\text { Malic } \\
\text { acid }\end{array}$ & $\begin{array}{c}\text { Fructose and } \\
\text { citric acid }\end{array}$ & $\begin{array}{c}\text { Quinic } \\
\text { acid }\end{array}$ & $\alpha$-Gluose & $\begin{array}{c}\beta \text {-Glucose } \\
\text { action }\end{array}$ & Inositol & Sucrose & $\begin{array}{c}\text { Chlorogenic } \\
\text { acid }\end{array}$ \\
\hline 0.94 & 1.26 & 1.70 & 1.33 & $\begin{array}{c}\text { Ratio } \\
1.57\end{array}$ & 0.92 & 1.01 & 2.00 \\
\hline
\end{tabular}

${ }^{2}$ Ratio of the concentration in external tissue (outer $3 \mathrm{~mm}$ ) to the concentration in interior tissue $\left(\mathrm{mg} \cdot \mathrm{g}^{-1}\right.$ fresh wt).

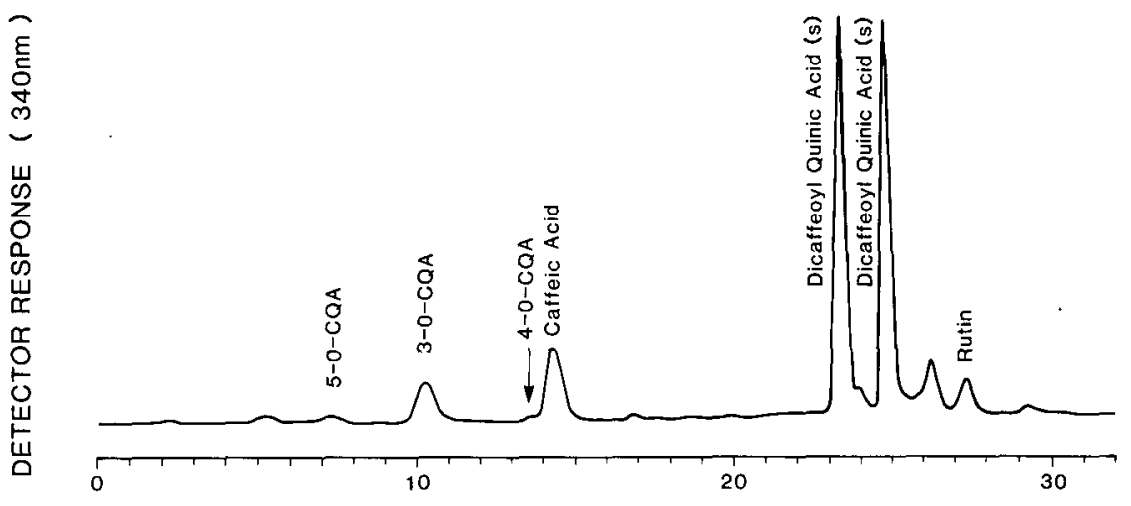

TIME ( MIN )

Fig. 1. High-performance liquid chromatography of phenolics from the external tissue of stored (3 months) 'Centennial' sweetpotato storage roots (CQA = caffeoylquinic acid).

tific, Pittsburgh), and $30 \mu \mathrm{l}$ of sample was injected (Valco loop injection valve) onto a column system consisting of a 5-cm Whatman guard column (packed with CO:PELL ODS, Whatman) preceding a $4.6 \mathrm{~mm}$ id. $\times$ $30-\mathrm{cm}$ Waters $\mu$ Bondapak $\mathrm{C}_{18}$ column. A concave gradient from $13 \% \mathrm{MeOH}: \mathrm{H}_{2} \mathrm{O}$ to $50 \% \mathrm{MeOH}: \mathrm{H}_{2} 0$, flow rate of $1.5 \mathrm{ml} \cdot \mathrm{min}^{-1}$, and $340 \mathrm{~nm}$ detection were used. The $13 \%$ $\mathrm{MeOH}: \mathrm{H}_{2} \mathrm{O}$ solvent contained $0.08 \mathrm{M}$ $\mathrm{KH}_{2} \mathrm{PO}_{4}$ buffer, adjusted to $\mathrm{pH} 4.45$ with dilute $\mathrm{H}_{3} \mathrm{PO}_{4}$.

Chlorogenic acid, caffeic acid, the dicaffeoylquinic acids, and rutin were identified by coinjection of standards and ultraviolet spectra obtained using a Hewlett-Packard Model 1040 diode array detector. Commercial Nicotiana tabacum L. (Court, 1977) and $N$. goodspeedii L. leaf (Snook et al., 1986) extracts were used to determine the retention times of the 4-0- and 5-0-caffeoylquinic acids. The concentration of chlorogenic acid in each sample, as determined by GC, was used as the "internal standard" in the identical samples for HPLC quantitation of 4-0and 5-0-CQA and the dicaffeoylquinic acids, GC-determined chlorogenic acid levels in plant tissues are essentially identical to those obtained by HPLC (Snook and Chortyk, 1982). The chromatographic response of the dicaffeoylquinic acids was assumed to be twice that of chlorogenic acid.

Caffeic acid was isolated and characterized in six 'Centennial' roots that had been stored for 3 months. The roots were peeled to give $180 \mathrm{~g}$ of external tissue, homogenized in $\mathrm{MeOH}$ with a Waring blender, extracted for $30 \mathrm{~min}$ by ultrasonication, and filtered. The $\mathrm{MeOH}: \mathrm{H}_{2} \mathrm{O}$ filtrate was evaporated until only $\mathrm{H}_{2} \mathrm{O}$ remained, and chromatographed on a $\mathrm{C}_{18}$ reverse-phase column (Waters PrepPak500 repacked into a $2.5 \mathrm{~cm}$ id. $\times$ 58-cm Cheminert LC column; Universal Scientific, Atlanta), and eluted with a linear gradient of $\mathrm{H}_{2} \mathrm{O}$ to $\mathrm{MeOH}$ over 400 $\mathrm{min}$ at $2 \mathrm{ml} \cdot \mathrm{min}^{-1}$. The $8-\mathrm{ml}$ fractions were monitored by HPLC and those containing the caffeic acid were combined and evaporated to dryness. Ultraviolet and HPLC and GC (trimethylsilyl derivative) retention and GC/ MS data of the isolate were found to be identical to a standard sample of caffeic acid.

Large differences in concentrations of simple sugars were found among cultivars (Table 1). Sucrose was the most abundant sugar in surface tissues (external) of the roots in all cultivars, and 'Resisto' and 'Regal' contained the highest and the lowest concentration, respectively. The concentration of $\beta$ glucose was consistently higher than that of $\alpha$-glucose in all cultivars. The individual cultivars were ranked in the order 'Jewel' > 'Regal' $\approx$ 'Centennial' > 'Resisto' based on both $\alpha$ - and $\beta$-glucose concentration. The concentration of glucose could not be compared directly to that of fructose due to coelution of fructose and citric acid. Inositol was detected at low levels in all cultivars. 'Jewel' contained the highest concentration of total sugars and 'Regal' the lowest (fresh-weight basis).

Citric and malic acids, the two most abundant organic acids in raw sweetpotatoes (Picha, 1985a), were also detected (Table 1). The least susceptible cultivars to the sweetpotato weevil ('Regal' and 'Resisto') had much higher concentrations of malic acid than the highly susceptible 'Centennial' (Table 1). Picha (1985a) reported an inverse correlation between the concentration of citric acid and malic acid; however, this could not be confirmed in the present study due to coelution of citric acid and fructose on the GC column. The combined citric acid/fructose concentra- tion was most abundant in 'Jewel'. Based on previous reports of the concentration of organic acid (Picha, 1985a) and sugars (Picha, 1985b, 1987), 'Jewel' probably had the highest concentration of citric acid. There was no direct relationship between the level of quinic acid (Table 1) (the alcohol moiety of chlorogenic acid) and chlorogenic acid (Table 2). There were, however, significant differences between cultivars for all chemicals measured.

We obtained baseline resolutions of 5-OCQA (neochlorogenic acid), 3-O-CQA (chlorogenic acid), 4-O-CQA, caffeic acid, rutin, and several other phenolics. Consistent with Walter et al. (1979) and Walter and Schadel (1981), but not Thompson (1981), we found only trace levels (i.e., <0.05-0.1 $\left.\mathrm{mg} \cdot \mathrm{g}^{-1}\right)$ of 5-O-CQA and 4-O-CQA in the freshly harvested storage roots. Walter et al. (1979) and Walter and Schadel (1981) reported that 5-O-CQA was not present in freshly harvested 'Jewel' roots, but becomes detectable $\approx 4$ weeks after harvest. They did not find 4-O-CQA in 'Centennial' and 'Jewel' at harvest or after storage. Thompson (1981). however, reported the presence of 4-O-CQA in these cultivars at harvest and after storage.

Critical to the separation of these phenols is the $\mathrm{pH}$ of the eluting solvent. Krause and Strack (1979) have investigated the effect of $\mathrm{pH}$ on the elution order of the three isomers of caffeoylquinic acid. They showed that the elution of 5-O-CQA was not affected in the $\mathrm{pH}$ range of 2 to 6 and always eluted before the other two isomers. We have found this to be true for a number of reverse-phase columns and solvents (Snook and Chortyk, 1982). The elution of 3-O- and 4-O-CQA, is, however, dramatically affected by $\mathrm{pH}$. Depending on $\mathrm{pH}$, a complete reversal of the order of elution of the two isomers or coelution can be obtained (Krause and Strack, 1979). The elution of caffeic acid is also pHdependent. Reduction of the $\mathrm{pH}$ of the solvent used in this study from 4.45 (Fig. 1) to 3.0 resulted in coelution of 3-O- and 4-OCQA and in a shift of caffeic acid to a back shoulder on the merged CQA isomers. These results need to be considered when evaluating previously reported data.

We detected chlorogenic acid, caffeic acid, two isomers of dicaffeoylquinic acids (designated 1 and 2), and rutin in each cultivar (Table 2). Rutin (quercetin-3-ß-D-rutinoside), a flavonol found in many plants, was found in small amounts in all cultivars. Chlorogenic acid was the most abundant phenol in 'Regal' and dicaffeoylquinic acid1 in 'Centennial' and Resisto'. Interestingly, caffeic acid was the major phenol in 'Jewel'. Craft and Audia (1962) reported the presence of chlorogenic acid, umbelliferone, scopoletin, and rutin, but not caffeic acid, in sweetpotato roots using paper chromatography. The external root tissue contained $0.4 \%$ to $0.9 \%$ total phenolics on a fresh-weight basis, with 3-O-CQA and dicaffeoylquinic acids comprising $14 \%$ to $44 \%$ and $44 \%$ to $73 \%$ of this total, respectively (Table 2). Based on total phenolic content, the cultivars were ranked in the order 'Centennial' > 'Re- 
sisto' > 'Regal' $\approx$ 'Jewel'.

We also investigated the effect of storage on the concentration and distribution of polyphenols in 'Centennial'. After 3 months of storage, we found 5-O-CQA to be barely detectable, 4-O-CQA in trace amounts, and caffeic acid, which eluted just after 4-O-CQA, to be relatively abundant (Fig. 1).

The ratios of individual components between the exterior and interior root tissue varied substantially (Table 3 ). Even though the level of sucrose was almost the same in both locations, the concentration of hexose sugars was much higher in the external than in the interior tissue. The external tissue contained substantially high levels (in milligrams per gram) of quinic and chlorogenic acids.

Compounds we measured, possibly excluding malic acid, did not appear to be related to the susceptibility of the individual cultivars to the sweetpotato weevil. These components, however, may represent secodary factors in larval feeding and/or adult oviposition. The present data on the relative and absolute levels of each component have been used in development of an artificial diet for the weevil. This will allow determining which components of the sweetpotato are important in behavior modification and nutrition of the insect-information that can be used in breeding for resistance.

\section{Literature Cited}

Court, W.A. 1977. High performance reversedphase liquid chromatography of naturally occurring phenolic compounds. J. Chromatog. 130:287-291.
Craft, C.C. and W.V. Audia. 1962. Phenolic substances associated with wound-barrier formation in vegetables. Bot. Gaz. 123:211-219.

Jones, A., P.D. Dukes, J.M. Schalk, M.G. Hamilton, M.A. Mullen, R.A. Baumgardner, D.R. Paterson, and T.E. Boswell. 1983. 'Resisto' sweet potato. HortScience 18:251-252.

Jones, A., P.D. Dukes, J.M. Schalk, M.G. Hamilton, M.A. Mullen, R.A. Baumgardner, D.R. Paterson, and T.E. Boswell. 1985. 'Regal' sweet potato. HortScience 20:781-782.

Krause, J. and D. Strack. 1979. High-performance liquid chromatographic separation of glucose esters and quinic acid esters of hydroxycinnamic acids. J. Chromatog. 176:465469.

Mullen, M. A., A. Jones, D.R. Paterson, and T.E. Boswell. 1985. Resistance of sweet potatoes to the sweet potato weevil, Cylas formicarius elegantulus (Summers). J. Entomol. Sci. 20:345350.

Nottingham, S. F., K.-C. Son, D.D. Wilson, R.F. Severson, and S.J. Kays. 1989a. Feeding and oviposition preferences of sweet potato weevil, Cylas formicarius elegantulus (Summers), on storage roots of sweet potato cultivars with differing surface chemistries. J. Chem. Ecol. 15:895-903.

Nottingham, S. F., K.-C. Son, R.F. Severson, R.F. Arrendale, and S.J. Kays. 1989b. Attraction of adult sweet potato weevils, Cylas formicarius elegantulus (Summers), (Coleoptera: Curculionidae), to sweet potato leaf and root volatiles. J. Chem. Ecol. 15:1095-1106.

Nottingham, S. F., D.D. Wilson, R.F. Severson, and S.J. Kays. 1987. Feeding and oviposition preferences of the sweet potato weevil, Cylas formicarius elegantulus, on the outer periderm and exposed inner core of storage roots of selected sweet potato cultivars. Entomol. Expt. Appl. 45:271-275.

Picha, D.H. 1985a. Organic acid determination in sweet potatoes by HPLC. J. Agr. Food Chem. 33:743-745.

Picha, D.H. 1985b. HPLC deterrnination of sugars in raw and baked sweet potatoes. J. Food Sci. 50:1189-1190.

Picha, D.H. 1987. Carbohydrate changes in sweet potatoes during curing and storage. J. Amer. Soc. Hort. Sci. 112:89-92.

SAS Institute. 1985. SAS user's guide: Statistics. SAS Institute, Cary, N.C.

Snook, M.E. and O.T. Chortyk. 1982. An improved extraction-HPLC method for tobacco polyphenols. Tobacco Sci. 26:25-29.

Snook, M. E., P.F. Mason, and V.A. Sisson. 1986. Polyphenols in the Nicotiana species. Tobacco Sci. 30:43-49.

Son, K.-C., R.F. Severson, R.F. Arrendale, and S.J. Kays. 1990. Isolation and characterization of pentacyclic triterpene ovipositional stimulant for the sweet potato weevil from Ipomoea $\mathrm{ba}$ tatas (L.) Lam. J. Agr. Food Chem. 38:134137.

Sutherland, J.A. 1986. A review of the biology and control of the sweetpotato weevil Cylas formicarius (Fab). Trop. Pest Mgt. 32:304-315.

Thompson, D.P. 1981. Chlorogenic acid and other phenolic compounds in fourteen sweet potato cultivars. J. Food Sci. 46:738-740.

Walter, W. M., Jr., A.E. Purcell, and G.K. McCollum. 1979. Use of high-pressure liquid chromatography for analysis of sweet potato phenolics. J. Agr. Food Chem. 27:938-941.

Walter, W. M., Jr., and W.E. Schadel. 1981. Distribution of phenols in 'Jewel' sweet potato [Ipomoea batatas (L.) Lam.] roots. J. Agr. Food Chem. 29:904-906.

Wilson, D. D., K.-C. Son, S.F. Nottingham, R.F. Severson, and S.J. Kays. 1989. Characterization of an oviposition stimulant from the surface of sweet potato Ipomoea batatas storage roots for the sweet potato weevil, Cylas formicarius elegantulus. Entomol. Expt. Appl. 51:71-75. 